\title{
CYTOLOGICAL SURVEY OF CONJUNCTIVAL SMEARS FROM ABORIGINAL SCHOOL CHILDREN AT YALATA, SOUTH AUSTRALIA*
}

\author{
BY \\ D. HARDY $\dagger$, P. G. SURMAN, AND W. H. HOWARTH \\ Institute of Medical and Veterinary Science, Adelaide, South Australia
}

SURVEYs in Australia have shown that trachoma is present among the aborigines (Webb, 1957; Flynn, 1957; Yates, 1963). Extensive surveys of school children of all races have been carried out in Western Australia (Mann, 1960). The diagnosis of trachoma in these surveys has been based on clinical grounds. An annotation (Lancet, 1964) drew attention to the presence of the disease in South Australia and emphasized the need for laboratory investigations. Cytological examination of conjunctival smears has been used as a basis for diagnosis of trachoma in this survey.

At a preliminary survey at Yalata, South Australia, it was noted that clinical trachoma was evident among the majority of aborigines. Conjunctival curettings were taken from ten aboriginal school children aged 6 to 13 and smears stained by the Giemsa method. Five of these smears were positive for trachoma. One child aged 6 (No. 1022) had gross clinical signs of the disease with indurated eyelids, $2 \mathrm{~mm}$. of pannus and trichiasis. Virus was isolated from this child and treatment was instituted immediately. It was decided in view of these results to examine the eye scrapings from all the children at the Yalata Mission School, and on March 29, 1965, curettings were taken from 73 of the 74 children attending the school (one child aged 6 refused to have this done).

Yalata Lutheran Mission is situated in South Australia, 130 miles west of Ceduna in the Nullabor Plain about 15 miles from the coast and about 400 miles directly north-west of Adelaide. The average mean temperature in summer is $95^{\circ} \mathrm{F}$ and in winter $70^{\circ} \mathrm{F}$. The annual rainfall averages $8^{\prime \prime}$, the altitude being $115^{\prime}$ above sea level.

There are about 400 aborigines on the reserve who live a semi-nomadic life with no permanent accommodation. Their economic status can be described as primitive, and their main occupation is making boomerangs, spears, etc., for sale by the Mission. The 74 children who attend the school in four classes receive two meals daily at the school and are in a good nutritional state.

Water in this region is in very short supply and is brought in a watercart to the aboriginal camp site by the Mission. Work is progressing on providing washing facilities at the school and it is intended that the school children shall wash and change into uniform on arriving at school when this work is completed.

\section{Methods}

The upper eyelid was everted and the conjunctiva scraped with a chalazion curette. The scraping was smeared on a slide previously cleaned with alcohol, allowed to dry in the majority of cases,

*Received for publication August 12, 1965.

† Address for reprints: Department of Microbiology, University of Adelaide, Adelaide, South Australia. 
then fixed in absolute methanol for 5 minutes. The smears were later stained by the following method:

Stock Giemsa $1 \mathrm{~g}$. powder (G. T. Gurr) was dissolved in $66 \mathrm{ml}$. glycerol AR, by heating at $56^{\circ} \mathrm{C}$. overnight with occasional shaking, and then $66 \mathrm{ml}$. methanol AR was added.

Buffer (pH 7.0) was prepared according to the method of Mackie and McCartney (1960).

The working stain was prepared in $100 \mathrm{ml}$. volumes by mixing $3 \mathrm{ml}$. methanol AR, $2.5 \mathrm{ml}$. stock Giemsa, and buffer to $100 \mathrm{ml}$. This solution was filtered through a Whatman No. 1 filter $11 \mathrm{~cm}$. in diameter. The smears were stained overnight for approximately $18 \mathrm{hrs}$, washed with buffer, blotted dry, and mounted. Fresh stain was prepared for each batch of slides. This method was found to produce the most uniform staining of the smears with minimal colour variation between slides.

Smears were examined at a magnification of $\times 400$ using wide-angle eyepieces for (1) elementary body and initial body forms, (2) accompanying cytology. Doubtful inclusions were examined at $\times 1,000$ magnification.

The typical elementary body and initial body inclusions have been described (Halberstaedter and von Prowazek, 1907; Braley, 1940; Thygeson, 1951). The accompanying cytology of exudates, conjunctival scrapings, and follicular expressions has been explored as a diagnostic aid in trachoma. Various cytological patterns have been described (Thygeson, 1946; Sezer, 1951; W.H.O., 1962). In the present survey the following features were consistently seen:

(a) Neutrophil polymorphonuclear leucocytes

(b) Lymphoblasts

(c) Plasma cells

(d) Multinucleated epithelial cells

(e) Large macrophages (Leber cells).

These features together were taken to represent typical accompanying cytology. Smears designated as "positive" had epithelial cells with typical inclusions showing elementary bodies. These slides also showed all the cytological features described above. Smears designated "cytology positive" had no epithelial cells with inclusions but had all the other cellular features described above. "Negative" smears showed no inclusions and an incomplete cytological picture. In fact not one of the 73 smears showed normal conjunctival cytology.

\section{Results}

On the above criteria the smears of the 73 school children showed 24 positive, 18 cytology positive, and 31 negative. The age distribution of these results is shown in Fig. 1. The smear of child No. 1022, aged 6, originally positive, who had been treated, was now negative, but has been included in Fig. 1 as positive.

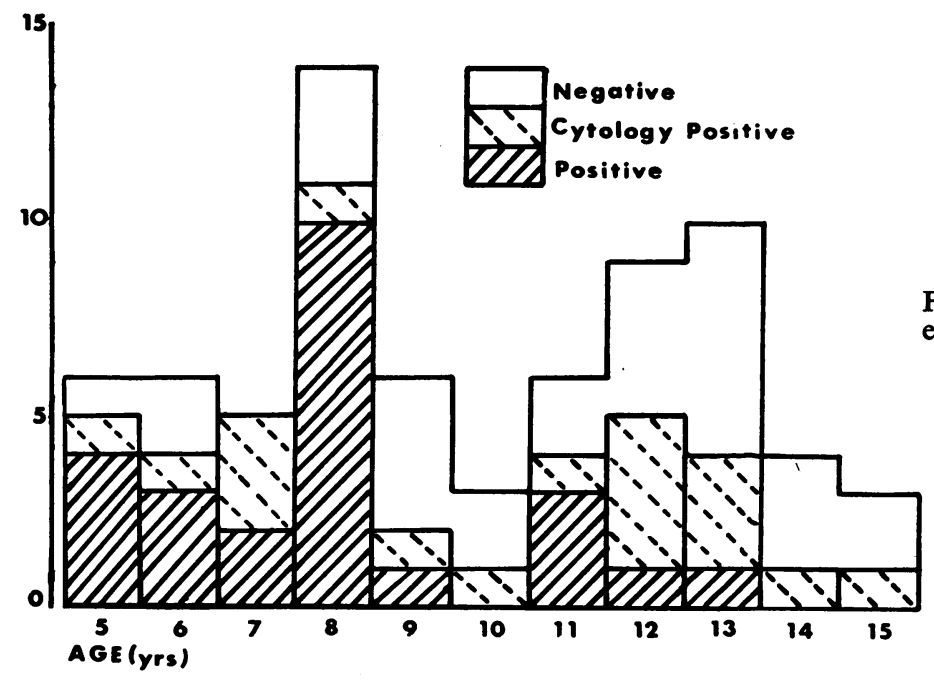

FIG. 1.-Cytological findings in eye smears, by age. 


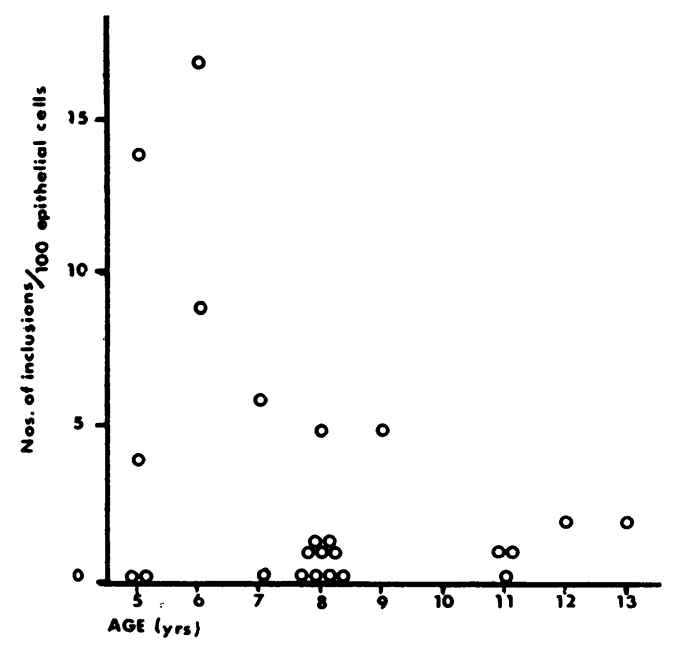

These results suggest that there is an increased incidence of active disease in the younger age groups. In an attempt to clarify this, the smears were reviewed and the number of epithelial cells with typical inclusions per 100 epithelial cells on the smear was determined (Fig. 2). If no inclusions were seen in 500 epithelial cells counted at random, this figure was put as 0 although the smear did in fact have cells with inclusions.

Fig. 2.-Distribution of numbers of inclusions per 100 epithelial cells in positive eye smears, by age.

\section{Summary}

Of 73 aboriginal school children at Yalata Lutheran Mission School, South Australia, 25 had conjunctival cytology consistent with active infective trachoma. A further eighteen children had cytological changes suggestive of active disease. All the children had abnormal conjunctival cytology.

The active disease was more prevalent in the younger age groups.

A pattern of cytology features in the conjunctival smear accompanies acute trachoma infection and is useful in evaluating smears not showing typical inclusion bodies.

This work was supported by grants from the National Health and Medical Research Council and the Pfizer Corporation.

\section{REFERENCES}

Braley, A. (1940). Arch. Ophthal. (Chicago), 24, 681.

FlynN, F. (1957). Med. J. Aust., 2, 269.

Halberstaedter, K., and ProwazeK, S. von (1907). Dtsch. med. Wschr., 33, 1285.

Lancet (1964), 1, 422.

MACKIE, T. J., and MCCARTNEY, J. E. (1960). “Handbook of Bacteriology", 10th ed., ed. R. Cruickshank, p. 130. Livingstone, Edinburgh and London.

MANN, I. (1960). Brit. J. Ophthal., 44, 321.

SEZER, F. N. (1951). Amer. J. Ophthal., 34, 1709.

THYGESON, P. (1946). Ibid., 29, 1499. (1951). Ibid., 34, no. 5, pt 2, p. 7.

WebB, R. C. (1957). Med. J. Aust., 1, 460.

World Health Organization (1962). "Technical Report Series, No. 234". Expert Committee on Trachoma, Third Report, p. 6, W.H.O. Geneva.

Yates, P. C. (1963). Med. J. Aust., 1, 828. 